\title{
How Does Israel Absorb International Aid Meant for Palestinians
}

\author{
Mahmoud M. Sabra \\ Associate Professor of Applied Economics, Al-Azhar University-Gaza, Palestine \\ Received May 29, 2021; Revised August 16, 2021; Accepted September 8, 2021
}

\section{Cite This Paper in the following Citation Styles}

(a): [1] Mahmoud M. Sabra , "How Does Israel Absorb International Aid Meant for Palestinians," Advances in Economics and Business, Vol. 9, No. 3, pp. 65 - 73, 2021. DOI: 10.13189/aeb.2021.090302.

(b): Mahmoud M. Sabra (2021). How Does Israel Absorb International Aid Meant for Palestinians. Advances in Economics and Business, 9(3), 65 - 73. DOI: 10.13189/aeb.2021.090302.

Copyright $\mathrm{C} 2021$ by authors, all rights reserved. Authors agree that this article remains permanently open access under the terms of the Creative Commons Attribution License 4.0 International License

\begin{abstract}
International aid to Palestinians is one of the highest in the world. Meanwhile, the need for such aid is on the increase. Under the strict occupation policies, whether political, economic or military, the majority of international aid is absorbed by the Israeli economy render the Palestinian economy completely dependent. Four simultaneous equations were estimated using the "Three Stage Least Squares" to detect the impact of Official Development Assistance (ODA) on growth, domestic savings, imports from the greater world and Israel. Available yearly time series data for Palestine from 2000 to 2019 used within the model were estimated. We estimate the international aid propensity to imports from the greater world and Israel, besides the impact on growth and domestic savings. We found that ODA is associated negatively with growth, crowds out domestic savings and increases imports from Israel more than from the greater world. ODA marginal propensity to import from Israel is twice and half higher than the marginal propensity to total imports, which indicates the influence of economic accords and occupation procedures. In addition, Israel absorbs directly one-fourth of each dollar donated to Palestinian economy, and higher absorption is potential in the long run. Correlation has been measured between ODA and Palestinian trade deficit with Israel, and we found that more than $87 \%$ of aid ends up in the Israeli economy. A series of recommendations were provided including ending of the unilateral trade union imposed by Israel.
\end{abstract}

Keywords ODA, Economic Growth, Domestic Savings, Propensity to Imports, Simultaneous Equations, Palestinian Economy
JEL Classification: F14, F35, F43, C32, F16, O24, O43, P45

\section{Introduction}

Palestine enjoys one of the highest per capita Official Development Assistance (ODA) around the world. This aid ranges from 327 to 602 US\$ per capita with an average of 500 US\$ for the period from 2000 to 2019, in constant prices $^{1}$. At the same time, ODA percentage to GDP ranges $15-34 \%$, in constant prices, with an average of around $22 \%$ of real $\mathrm{GDP}^{2}$.

Aid plays an important role in humanitarian relief, life-saving interventions and bridging saving-investment and exports-imports gap whereas supplement other international capital inflows, limited exports revenues and low tax base and enhance investment directly or through government expenditure.

International aid is an international purchasing power to enhance demand on goods and services that raise prices and wages of non-tradable sectors causing resource movement effect toward these sectors, and reducing productive sectors base and enforcing imports. In addition, aid increases final consumption directly or through government spending and enlarge public employment that

\footnotetext{
${ }^{1}$ Authors' calculation based on World Bank database using constant ODA and population.

2 Authors' calculation based on World Bank database using constant ODA and Real GDP.
} 
under narrow production base accelerates more imports and increases the need for more future aid, creating aid dependency.

The long-standing occupation, coupled with multiple military engagements and over 15 year blockade on the Gaza Strip, separation between Gaza and West Bank, unilateral trade union, multi-currency monetary system, restricting movement of goods, services and production factor intra-Palestine and inter Palestine and greater world, Israeli control of air-land-sea borders create high engagement in trade with or through Israel and high economic dependency on Israel. Therefore, trade balance between Palestine and Israel suffers from a severe and chronic shortage, which indicates a deep dependency on Israeli economy.

These severe economic circumstances transform Palestinian economy to an economic backyard to the Israeli economy. It provides obligatory cheap economic factors and raw materials from one side, and Israel exploits the Palestinian market and absorbs potential purchasing power, including that boosted by aid.

The study estimates the impact of Official Development Assistance (ODA) on Palestinian imports including those from Israel, considering the impact of ODA on both economic growth and domestic savings.

We proceed as follows: firstly we review the literature, that not available empirically for Palestine, secondly we derive our model and then introduce data, methodology and estimation. Finally results and conclude are given.

\section{Literature Review}

ODA plays a significant role in the developing or recipient countries, and it has been widely discussed in the economic literature. In fact, ODA has an essential role, more than any other international capital inflow, in areas with conflict. In addition, ODA is an important source in developing countries, which have a low exports returns and narrow tax base. Hence, ODA impact on economic growth and bridging both saving-investment and exports-imports gap have a high profile in the literature. Furthermore, a special concern rises on the Palestinian economy, occupied and receives high ODA, is whether ODA is redirected to the benefits of Israeli economy or not.

On the one hand, ODA may complement domestic savings and enforce investment and economic growth. In such cases, ODA injects productive sectors with higher levels of physical and human capital that increases productivity, exports, (Sabra, 2021a), growth, accumulating more capital and creating more investment. In such cases, ODA participates in bridging the foreign exchange gap, establishes channels to better technology and managerial skills, Chenery and Strout, (1966). Hence, this, should decrease the need for more international aid.
On the other hand, ODA is an international purchasing power added to local demand that increase prices in non-tradable sectors and increases imports in tradable sectors. This, in fact, increases consumption, private and public, changes the consumption behavior, crowds out local savings, increases imported goods of productive sectors, decreases the competitiveness of productive tradable sectors, and increases also imports of non-tradable sectors inputs. Such scenario deepening both savings-investment gap and exports-imports gap, also does cause aid dependency.

Moreover, Morrissey, (2001) indicated that, ODA may enforce possibility to accumulate more capital goods and technology, which promotes productivity and endogenous technological changes. This can be realized in case of good fiscal, monetary and trade policies, meanwhile, little impact stands in case of such poor policies, Burnside and Dollar, (2000). In fact, an adverse impact can stand in constrained, restricted and absence of such institutional and economic policies, such as the Palestinian case, whereas the fiscal policy is a reflection of the Israeli one, and the monetary and trade policies are completely replaced by the Israeli policies. This is because of the absence of Palestinian currency, and imposing unilateral Israeli trade union, basing on Paris accord ${ }^{3}$. McGillivray et al. (2006) suggest that aid effectiveness depends on institutional quality. Moreover, it is influenced by political, external and climate conditions and indicates that aid has a decreasing return. In fact, this clarifies that the occupation control of borders and creation of local fragmentation based on security reasons deeply worsening the political and economic conditions and stability, furthermore, it deeply and negatively impacts on macroeconomics governmental efforts. In fact, these occupation policies intend to transform the Palestinian economy to a backyard serves the Israeli one, through absorbing demand power, especially international one, and exploit economic resources, especially labor and natural resources, and open the Palestinian market to the surplus of Israeli economic sectors' products. Hence, aid has a positive impact on growth when it has not an adverse impact on savings and therefore investment, productivity and production, Sabra, \& Sartawi, (2015), \& Eltalla, (2016). However, if the aid increases growth, saving, investment and supports productive sectors, it would substitute imports, and improve the trade deficit, through enhancing production locally instead of importing, enhanced by development impacts of aid, although the marginal positive impacts on imports resulted from increasing income and demand including demand on foreign goods, (Sabra, 2021b). In addition, ODA is highly

The Paris Protocol, signed between the Palestine Liberation Organization (PLO) and Israel in Paris in 1994, organized the economic relations between Palestine and Israel for the interim period that should be end within five years after Oslo agreement, which in turn organize the Political relations between both parties. 
positively associate with donors' exports and increase recipients' countries imports, as long as, ODA normally alleviate trade barriers between both donors and recipients. This in fact has an impact on recipients' economies basing on whether these imports are convenient to national economic plans or not.

Djankov et al. (2006) found that ODA has a negative direct impact on economic growth, and it does not increase investment, meanwhile, it impacts positively on government expenditure. In addition, rent seeking behavior activities among parties in power enhance government spending, reduce investment, imply non-productive use of resources and increases openness Djankov et al. (2006), which redirect aid resources toward imports and associate negatively with savings. The Palestinian case shows clearly, that the huge available easy resources "ODA" make form main pillar and seminal cause to the Palestinian political continuous division, besides other reasons. In addition, exceeding the optimal size of government reflects negatively on growth, Sabra, (2016). In other words, the positive or negative impact of aid depends on whether government spends on public investment or consumption, respectively Djankov et al. (2006), and whether it exceeds the government optimal size or not. If ODA enhanced investment and growth that must replace imports, and if the impact on growth, saving and investment is negative that may enhance public current expenditure and consumption, which increases imports directly and indirectly, and change consumption behavior in the long run. In fact, big government size and high current government spending and expanding bureaucratic staff are finance in a way or another through the foreign aid, in the Palestinian case under the limited resources and high aid level.

In addition, foreign aid inflows appreciate real exchange rate, which impedes the exporting sector, that is relatively small and necessary for development in developing countries, Bevan, (2005), Adam (2005), Adam and Bevan, (2005) and in addition increase imports in different sectors. Agriculture sector is usually one of the main exporting sectors in developing countries including Palestine, which is greatly affected by exchange rate appreciation impacts strongly and negatively on fragile workers and businesses, Benjamin et al. (1989), Stevens (2003), Rajan and Subramanian, (2005), Adam and Bevan, (2005), which may create aid-dependency for humanitarian reasons that increase food imports. However, exchange rate appreciation reflects on overall prices in economy, which increases inflation. Palestine such as a small open country with few resources entrapped in a vicious circle of poverty because of occupation procedures, low incomes, the low saving ratios and retreating productive sectors, which creates "landfill" market of low quality and used products from the Israeli economy ${ }^{4}$.

Furthermore, ODA ${ }^{5}$ inflows as an international purchasing power increase demand in the economy, both tradable and non-tradable sectors. This, in fact, increases prices and workers' wages and firms' profits in the non-tradable sectors, such as construction, education and health care, under the assumption of fixed supply of skilled labor. In addition, long continuous Israeli occupation and several military escalation and destruction cause a huge shortage of physical and social infrastructure, such as roads, schools and hospitals, besides high population intensity that cause a huge need for public and private spending on construction including housing. Hence, higher prices, wages and profits in non-tradable sectors push the more efficient productive factors toward these sectors on the account of tradable sectors, under the assumptions of small open economy, which called "resource movement effect". The scenario is observable in, for instance less profitable, less efficient and less competitiveness in tradable sectors internationally, such as agriculture and industry, as a result of "resource movement effect", which decreases exports and increases imports of tradable goods, Rajan and Subramanian, (2011), Corden and Neary (1982). Furthermore, lower production of tradable sector and lower share to GDP as a result of lower productivity, and at the same time, high demand as a result of higher prices, wages and international aid cause more spending that called a "spending effect" and increases imports of tradable goods, considering that, it's cheaper in the international market than the local market. The previous different effects indicate the Dutch disease rising in Palestine.

In fact, Palestinian tradable sectors got radically shrunk in the last five decades including the period of Palestinian Authority (PA) presence. On the other hand, Palestinian non-tradable sectors such as services and construction, got highly expanded in the same period. For example, agriculture and industry sectors share to GDP decrease from $10.2 \%$ to $3.4 \%$, and $14 \%$ to $8.3 \%$, from 1994 to 2016, respectively ${ }^{6}$. Furthermore, workers in the Palestinian construction sector as a share to the work force increase from $5.6 \%, 10.4 \%, 9.9 \%$, to $14.9 \%$ in years 1971 , 1981, 1991 and 1993 respectively. This shows that Dutch disease is rising, before the PA period, in the Palestinian economy as a result of workers' remittance flows from Israel resulted from increasing demand on Palestinian workers in the $3 \mathrm{D}^{7}$ jobs.

As mentioned before, relative prices in the economy

\footnotetext{
${ }^{4}$ This is such as used furniture, clothes, cars, electric machines, semi expired products and others.

5 Similarly to remittances of Palestinian workers even in Israel or abroad especially in Gulf countries.

6 Author calculation, basing on PCBS statistics.

http://www.pcbs.gov.ps/statisticsIndicatorsTables.aspx?lang=ar\&table_id $=376$

7 Three D jobs referred to Difficult, Dangerous and Dirty work types, which decreases supply on it in the high income level areas.
} 
changes in favor of non-tradable sectors, which increase comparing to the tradable sectors. In fact, the high local relative prices will enhance tradable goods flows to the local economy as long as it enjoys higher prices, which means more imports. This in fact worsens the trade balance and increases the need for more aid to finance imports, which called "aid dependency effect". This, in addition, generates a low-growth economy and enhanced by high public spending financed by aid, and continues to crowd out the domestic savings, Mosley,(1980).

On the other hand, the high prices in the non-tradable sectors attract more efficient labor forces from the tradable sector and squeeze it, as shown in statistics before, which reduce the efficiency and competitiveness of exports sector, especially in the long run. This is called "Dutch disease effect". Furthermore, increased imports generated through strategic imports of raw materials such as those in the construction sector. In fact, Israel restricts the entrance of such materials and others except from or through ${ }^{8}$ Israel and basing on the surplus of productive Israeli sectors, such that they realize more political goals. This is what we called "Economic Shock for Political Purposes", besides prohibiting around 400 goods or raw materials to enter Gaza, which redirect Palestinian demand including that financed by aid to the Israeli economy.

Hever, (2015); and Tillekens, (2010) estimated Pearson correlation between aid and Palestinian trade deficit from 2000 to 2014 , and they found that around $72 \%$ of aid to Palestinians ends up in the Israeli economy. Similarly, we measured the correlation between ODA at current prices and Palestinian trade deficit with Israel, for the time series from 2000 to 2019 , and we found that more than $87 \%$ of aid ends up in the Israeli economy. This in fact indicates that dependency in deepening more aid to Palestine ends up in Israel during time.

Finally, growth in Palestine is driven by consumption and government expenditure that boost rent seeking behavior, and both are financed mainly by aid and remittances in addition, that way causing the Dutch disease, shrinking the productive base, moving resources from productive to non-productive activities and causing more imports and less savings, investment, exports and growth. This actually injects aid to Palestinians toward Israel, which controls Palestinian economy from different aspects.

\section{Model Derivation}

The study aims to investigate the impact of Official Development Assistance (ODA), constant prices, to

8 Various Israeli constraints whether military, financial or trade push Palestinians to import from abroad through Israeli firms, to facilitate their imports that transfer customs to the benefit of Israeli economy instead of Palestinian one.
Palestinians on each GDP, domestic savings, total imports and imports specifically from Israel. No previous work has been found investigating these relationships especially quantitatively. Consequently, no pioneer model stands, therefore, we derive our model, which can detect main goals of this research. We build four simultaneous equations, for the simultaneous analysis purposes, which is more reliable in analysis, interpretation and recommendations than single equation model. We regress different determinants on GDP, domestic savings, total imports and imports from Israel, whereas we include ODA in each equation, to detect its impact on these variables. Well known essential determinants in literature explain growth and GDP such as Gross Capital Formation (GCF), labor force and government expenditure are included in the first equation, besides ODA. In the second and fourth equations, we regress on imports from Israel and total imports, respectively, and include both GDP, as a main determinant and promoter for imports, and ODA to detect the imports elasticity for international aid. These two equations will detect whether goods imported internationally or those from Israel are higher sensitive for or attracted by international aid. The third equation detects the impact of ODA on domestic savings, besides imports from Israel and openness.

\subsection{Official Development Assistance (ODA) ${ }^{9}$}

Small open economies, such as Palestinian economy, are likely to import capital, primary and strategic goods. Aid finance such types of goods, as food, to face severe humanitarian situation, as well as finance construction materials for infrastructure needs and reconstructing what was destroyed as a result of Israeli military campaigns. Furthermore, fuel and intermediate goods are imported in Palestine. In fact, aid is filling the gap between exports and imports and the gap between consumption and production, whereas consumption is higher than production. Israeli policies use security justifications to maximize Israeli goods flow, Israeli production sectors or companies surplus to Palestinian territories using monopoly alliances between the two markets. Furthermore, the Israeli economic, military and trade policies, do shrink production base through interrupting movements of goods and production factors, increasing transport cost, long list of forbidden intermediate goods and trade and dumping policies. In fact, is a shock

\footnotetext{
${ }^{9}$ Official Development Assistance (ODA) which include grants, loans, and technical co-operation, and Other Official Flows (OOF) which includes grants to developing countries for representational or essentially commercial purposes; official bilateral transactions intended to promote development but having a grant element of less than $25 \%$; official bilateral transactions, whatever their grant element, that are primarily export-facilitating in purpose; the net acquisition by governments and central monetary institutions of securities issued by multilateral development banks at market terms; subsidies or grants to the private sector to soften its credits to developing countries; and finally funds in support of private investment.
} 
doctrine, it's an economic shock to realize a political and colonial goal.

ODA may cause more imports in two ways, first if ODA complements local investment, domestic savings and cause growth and income, which in turn, increases imports. Second, if ODA enhances the consumption behavior and crowd out domestic savings and increase imports. For these reasons, we detect the impact of ODA on, domestic saving and imports, besides the growth. Furthermore, the impact of ODA on imports from Israel and total imports. In fact, the impact goes in the same direction, as long as, all imports came from or through Israel, and the majority of imports are from Israel.

Our expectation is that ODA enhances private and public consumption and creates rent seeking in public behavior that would crowd out the domestic savings that would react negatively on investment, growth, in such cases, ODA increases imports as a result of higher relative prices in the local economy as a result of the international purchasing power and increasing demand on tradable sectors and non-tradable sectors, and emerging Dutch disease. Therefore, when ODA is positively associated with imports, it should negatively impact on domestic savings, and vice versa.

\subsection{Government Expenditure}

Government expenditure is a general government final expenditure, which includes all government current expenditures for purchases of goods and services and most expenditure on national defense and security. Government size in Palestine, which is government spending as a percentage of GDP, ranges from $23 \%$ to $32 \%{ }^{10}$ during the study period that indicates the importance of government role as a promoter of growth. In fact, the informal sector in Palestine is notably huge, Sabra et al. (2015), for several reasons such as dependency on Israeli economy, occupation control of borders and occupation restriction, which makes government relay on indirect taxes, such as customs and VAT collected by Israel, as long as the tax base is so weak as the result of the shadow economy dominance ${ }^{11}$. Easy resources such as aid enhances rent seeking behavior between political parties in power, Djankov et al. (2006), and may participate in creating political division. This undesired situation pushes on current public expenditure on count of capital public expenditure. The government expenditure is a main explanatory variable of economic growth, and it's a source of economic growth, Barro, (1990). The government expenditure is expected to have positive strong impact on growth.

\footnotetext{
${ }^{10}$ Author calculation basing on World Bank database.

${ }^{11}$ The size of shadow economy is between (57\%-88\%) of GDP, Sabra et al. (2015)
}

\subsection{Gross Capital Formation}

GCF is the gross capital formation, which represents the physical capital in economy, and participates essentially in boosting growth, increasing capital accumulation, output and exports. The increase in all physical and social capital and the acquisitions value of new or existing fixed assets by the business sector, governments and households, in an economy such as schools, construction of roads and railways and machinery enhances invention, innovation and overall productivity, also besides improving the human capital. More capital accumulation attracts FDI and other international capital inflows that enhance more employment, savings, growth, output, exports and bridging different gaps. We expect a positive impact on GDP as well as exports, whereas GCF captures the predictions of Romer (1987) and Lucas (1988) growth models which confirm that capital accumulation expansion increases increase growth, product and exports of a specific economy. In addition, it's a well-known explanatory variable in endogenous growth literature as a proxy of investment. A positive impact on growth should be emerged.

\subsection{Gross Domestic Product}

GDP is the best representative for income, demand and economic growth. GDP is included in the first equation as dependent variable and explained by different sources of growth such as government spending, labor force and GCF. These determinants are highly important to be presented with ODA to detect its impacts on GDP. Furthermore, GDP represents demand and income, which enhances imports that function of local income. GDP have to associated positively and strongly with imports.

\subsection{Labor Force}

The Palestinian economy is a labor abundant economy and labor exporting economy. Labor is a main source of growth and labor elasticity to growth is relatively high. In addition, Palestinians workers' remittances in Israel and abroad are a main source of Palestinians income. We include labor force in the first equation as a source of Palestinian economy GDP, and expect a positive and highly elastic association with GDP.

\subsection{Domestic Savings}

Public and private consumption behavior are financed by foreign aid that increases consumption through imports and enhance consumption behavior in time. The inflationary current expenditure and consumption behavior financed by aid reduce domestic savings. This for instance refers to foreign saving provided to Palestinians in the form of aid crowds out the domestic savings, and increases consumption and imports 
especially those from Israel under the occupation constraints. This is all under the absence of real development plans. Furthermore, the negative impact of aid on domestic savings reduces investment and production base, which in turn increases imports again in time. Hence, we expect a negative impact on domestic savings, similarly to growth, and in addition, we expect a negative impact of imports on domestic savings as well. This may indicate imports type, which is for consumption purposes and not raw material or capital goods that increase production and income, and consequently increase domestic savings.

\subsection{Openness}

More trade openness and exposure must enhance imports. The Palestinian trade balance suffers from chronicle deficit. In fact, a small and highly open economy such as the Palestinian economy, which suffers from occupation restrictions, dumping policies and absence of controlling boarders and trade policy formulation.

Furthermore, greater openness associates positively on government size, namely government spending as a percentage of GDP, which plays as a stabilizer against external shocks, Sabra, (2016). This, in fact, enhances more government expenditure, which is already financed by aid that creates aid dependency effect. Hence, openness influences imports positively, as such, we expect a positive impact on imports.

\section{Empirical Model}

Time series data for Palestine was used for the years from 2000 to 2019 based on available information collected from the World Bank database and Palestinian Central Bureau of Statistics (PCBS). The multiple-equation model avoids any potential simultaneity bias that may occur in single-equation estimators. In addition, simultaneous-equation model allows for jointly determination of ODA impact on both Palestinian imports and imports from Israel, considering the impact on both growth including growth determinants, savings and considering openness also. Hence, we build a four-equation model captures the different estimators as follows:

$$
\begin{gathered}
\text { Ln GDPcon }=\beta_{0}+\beta_{1} \text { Ln GCF }+\beta_{2} \text { Ln Labor }+ \\
\beta_{3} \text { Ln Gov. E }+\beta_{4} \text { Ln ODAcon }+\epsilon \\
\text { Ln Imports. I }= \\
\alpha_{0}+\alpha_{1} \text { Ln ODAcon }+\alpha_{2} \text { Ln GDPcon }+v \\
\text { Ln Savings }= \\
\beta_{0}+\beta_{5} \text { Ln Imports. I }+\beta_{6} \text { Ln ODAcon }+ \\
\beta_{7} \text { Ln OPEN }+\epsilon
\end{gathered}
$$

$$
\begin{gathered}
\text { Ln Imports. T }= \\
\alpha_{0}+\alpha_{1} \text { Ln ODAcon }+\alpha_{2} \text { Ln GDPcon }+v
\end{gathered}
$$

Where: GDPcon represents the real growth, which is real Gross Domestic Product (GDP). GCF is the gross capital formation, which represents physical capital in the economy. Labor is the labor force. Gov.E is the government expenditure, which is the general government final consumption expenditure. ODAcon is Official Development Assistance in constant prices. Imports.I is the imports of goods and services from Israel. Savings is the domestic Palestinian savings. OPEN is the trade openness measured by the sum of exports plus imports as a share of GDP. Imports. T is the total Palestinian imports. And $\epsilon$ and $v$ are error terms. The parameters $\beta_{1}, \beta_{2}, \beta_{3}$ and $\beta_{4}$ represent the elasticities of economic growth with respect to GCF, labor, government expenditure and ODA, respectively. In addition, the parameter $\alpha_{1} \alpha_{2}$ represent the elasticities of imports from Israel and total imports with respect to ODA and GDP, respectively. The parameters $\beta_{5}, \beta_{6}$ and $\beta_{7}$ represent the elasticities of domestic savings with respect to ODA, GDP and openness, respectively. Model aims to detect the impact of ODA on growth, total imports, imports from Israel and domestic savings considering openness and growth determinants.

\section{Econometric Methodology}

The Three-Stage Least Squares (3SLS) is a well-known econometric technique and widely used in the literature. In fact, it is used to estimate the parameters of simultaneous equations when errors across the equations are not correlated and the equations concerned are over-identified or exactly identified, Mishra, (2008).

In addition, simultaneous-equation model allows for jointly determination of ODA impact on both Palestinian total imports and imports from Israel, considering the impact on both growth including growth determinants, savings and considering openness as well. Estimation of each equation individually might endure simultaneous equations bias due to the fact that some of the explanatory variables might not be truly exogenous. Consequently, we estimate the four equations simultaneously using the Three-Stage Least Squares technique (3SLS).

\section{Data}

This study uses yearly time series data of Palestinian economy for the period from 2000 to 2019. Model includes GDP in constant prices, Gross Capital Formation (GCF) formerly gross domestic investment, consists of outlays on additions to the fixed assets of the economy plus net changes in the level of inventories. In addition, labour force, government size, as determinants of growth 
were included. ODA in constant prices, domestic savings, openness, imports from Israel and total imports variables are included in the model. ODA is the net official development assistance and official aid received. Trade openness measured by the sum of exports plus imports as a share of GDP. Government size is general government final consumption expenditure as a share of GDP. The proxies of variables are widely used in the previous literature. All raw data of variables are collected from World Development Indicators of the World Bank, except imports from Israel and total imports, which were collected from PCBS, Palestinian Central Bureau of Statistics database, besides openness which is calculated as exports plus imports divided by GDP. Limited missing values are still standing. All variables are taken in logarithm. We use variables in algorithm to get the elasticities, guarantee linearity and reduce any potential multicollinearity. STATA software has been used for the analysis.

\section{Empirical Results}

Table 1. Three-Stage Least Squares (3SLS) Simultaneous Analyses.

\begin{tabular}{|c|c|c|c|c|}
\hline \multicolumn{5}{|c|}{3 sls } \\
\hline & GDP con. & Imports.I & SAV & Imports.T \\
\hline Constant & $\begin{array}{c}9.6^{*} \\
(14.7)\end{array}$ & $\begin{array}{c}-20.6^{*} \\
(9.38)\end{array}$ & $\begin{array}{c}-6.61^{* * *} \\
(-1.77)\end{array}$ & $\begin{array}{c}-12.53^{*} \\
(-11.82)\end{array}$ \\
\hline ODA con. & $\begin{array}{c}-.083^{* *} \\
(-2.25)\end{array}$ & $\begin{array}{c}.26^{* * *} \\
(1.93)\end{array}$ & $\begin{array}{c}-.37^{* * *} \\
(1.65)\end{array}$ & $\begin{array}{c}.107^{* * *} \\
(1.68)\end{array}$ \\
\hline GDP con. & & $\begin{array}{c}1.01^{*} \\
(7.28)\end{array}$ & --- & $\begin{array}{c}1.42^{*} \\
(21.3)\end{array}$ \\
\hline OPEN & --- & --- & $-.92^{* *}$ & $(-2.02)$ \\
\hline Gov. Exp & $\begin{array}{c}.33^{*} \\
(6.29)\end{array}$ & --- & --- & --- \\
\hline GCF & $.1^{* *}$ & --- & --- & --- \\
\hline Labour & $\begin{array}{c}.2 .22) \\
(4.7)\end{array}$ & --- & --- & --- \\
\hline Imports.I & --- & & $\begin{array}{c}-.9 \\
(-5.14)\end{array}$ & --- \\
\hline Chi2 & $2450.7^{* * *}$ & $168.6^{* * *}$ & $108.9^{* * *}$ & $1110.5^{* * *}$ \\
\hline RMSE & .026 & .12 & .17 & .06 \\
\hline R2 & .99 & .90 & .84 & .98 \\
\hline Obs. & 19 & 19 & 19 & 19 \\
\hline
\end{tabular}

Figures in parentheses are $\mathrm{Z}$ statistics. Symbols $* * *, * * *$ indicate significant at $10 \%, 5 \%$, and $1 \%$ levels, respectively.

Source: Model estimations results using STATA software.

The estimated model shown in table 1 represents a robust estimation for the four equations. It presents a highly significant chi square and a tiny root mean square error value, which show model validity. All variables are significant either at $1 \%, 5 \%$ or $10 \%$ significance level. $\mathrm{R}$ squares are $0.84,0.9,0.98$ and 0.99 for the four equations, respectively, namely growth, imports from Israel, savings and total imports, which represents the inclusion of the main determinants of the explained variables. All signs are in line with the expectations and in accordance with the literature, in such subjects. In fact, replacing some proxies such GCF by GFCF, or employing other techniques such as Two-stages Least Squares (2SLS) doesn't change signs or magnitudes of the coefficients.

ODA associates negatively with both economic growth, represented by GDP, and domestic savings in time. At the same time, ODA associates positively with imports including that from Israel, taking into consideration, higher imports elasticity from Israel. ODA as an international purchasing power provided to Palestinians increases disposable income directly or through government expenditure (salaries and subsidies), which in turn increases demand on consumption goods, considering the low income level of categories benefit directly from aid. This increase in income and demand increases imports especially those from Israel, considering the Palestinian small open economy and retreating productive sectors, agriculture and industries. Furthermore, ODA marginal propensity to import from Israel is twice and a half the marginal propensity to total imports, which indicates the influence of economic accords, occupation procedures and including dependency of banking system, presence of monopolies engagements and the whole economy dependency on Israeli economy. Hence, Israel absorbs directly one-fourth of each dollar donated to Palestinian economy, meanwhile, more and more donation will be absorbed in the long run through destruction and reconstruction influenced by restricted Israeli system basing on surpluses in the productive Israeli sectors, considering monopoly engagements, monetary system dependency and absence of national vision and development plans. In addition, informal, illegal and invisible partnership between authority and capital monopoly in Palestine. In fact, such partnership may find deeper roots in the Israeli monopolies under the auspices of Israeli security power from one side, and supported by donor policies, from the other side.

Furthermore, ODA associates negatively with domestic savings, for instance international savings crowds domestic savings. In fact, this indicates that international aid enhance individuals consumption behavior, seeking consumption credit and rent seeking behavior in government and in political parties participate in power. This, in turn, attracts more imports, especially from Israel, as shown in the results, more openness and more imports from Israel crowds out domestic savings and decease it, which denotes the consumption nature of imports, and imports from Israel swallows domestic savings, as long as, high elasticity reaches 0.9 .

On the other hand, GDP as a main determinant attracts foreign goods, as long as imports is a function of local income, shows higher elasticity to total imports that those from Israel which reflects Palestinian Authority directions to reduce dependency on Israel and reduce imports from 
Israel, although there is a notable success but the Palestinian economy is still stuck under Israeli restrictions namely political, institutional, economic and security.

Finally, government expenditure, labor and GCF are the main determinants and sources of Palestinian output, taking into consideration that Palestine has a labor intensive economy and has a relatively big size of government.

\section{Conclusion and Recommendations}

We conclude that ODA has been used for consumption purposes and current expenditure in the Palestinian economy during the last two decades. In addition, international aid influenced essentially the private and public economic behavior and caused distortion and inflation in credit, bureaucracy, economic and political system. This is under the assumptions of lack of Palestinian vision, plan and dominance of donor policies and strategies. Furthermore, occupation imposed a series of restrictions and policies such as unilateral trade system, controlling borders, controlling land and water and natural resources, restricting movement of goods and workers between and within the rest of Palestinian lands, permanent weakening of the productive Palestinian sectors whether through destructive military campaigns, or dumping, legal and military constraints and increasing the Palestinian trade costs, narrowing exports channels. Finally, the study found international aid increases imports from Israel than from anywhere else across the greater world. ODA marginal propensity to import from Israel is twice and a half the marginal propensity to total imports, which indicates the influence of economic accords and occupation procedures. In addition, Israel absorbs directly one-fourth of each dollar donated to Palestinian economy, and higher absorption is potential in the long run. Correlation has been measured between ODA and Palestinian trade deficit with Israel for 2000-2019 period, and the study found that more than $87 \%$ of aid ends up in the Israeli economy. Hever, (2015); and Tillekens, (2010) estimated correlation for $2000-2014$ period, and they found that around $72 \%$ of aid to Palestinians ends up in the Israeli economy. This in fact indicates that dependency is deepening and more aid to Palestine ends up in Israel during time.

The study concludes and recommends set of an ambitious series of policies to rationalize using ODA from current spending and humanitarian relief for sustainable use to support physical and social infrastructure, and productive sectors. In fact, high consumption level, big bureaucratic civil and police staff, fungibility in the public budget and misallocation within NGOs for high salaries and duplication of activities and projects cause an inefficient use of aid. Hence, new real plans to complement domestic savings and reduce consumption culture and minimize wasting and duplication of expenditure, and expansion in current spending are recommended. In addition, more trade integration with Arab world and other countries in the region alleviates trade dependency on Israel that needs political efforts, whereas, the economic constraints are subject to the political regimes. Furthermore, ending the unilateral trade union imposed by Israel, and liberalization of trade, monetary and financial system are still essential. Dollarization or initiating the Palestinian currency can lower Israeli control, besides arranging agreements such as RO-RO ${ }^{12}$ (Roll-on Roll-off) agreements to trade through Arab ports and boarders make a greater transformative and emancipatory rational.

\section{REFERENCES}

[1] Adam, C. (2005). Exogenous Inflows and Real Exchange Rates: Theoretical Quirk or Empirical Reality? The macroeconomic management of foreign aid.

[2] Adam, C. S. and Bevan, D. L. (2005). Fiscal deficits and growth in developing countries. Journal of Public Economics, 89(4), 571-597.

[3] Barro, R. J. (1990). Government Spending in a Simple Model of Endogenous Growth. Journal of Political Economy, 98(5 pt 2).

[4] Benjamin, N. C. Devarajan, S. and Weiner, R. J. (1989). The Dutch disease in a developing country, oil reserves in Cameroon. Journal of Development Economics, 30, 71-92.

[5] Bevan, D. (2005). An analytical overview of aid absorption: Recognizing and avoiding macroeconomic

[6] hazards. In International Monetary Fund Seminar on Foreign Aid and Macroeconomic Management (pp. 14-15).

[7] Burnside, C. and Dollar, D. (2000). Aid, policies, and growth. American Economic Review, 90, 847- 868.

[8] Chenery H. and Strout, A. (1966). Foreign assistance and economic development. The American Economic Review, 56(4), 679-753.

[9] Corden W.M. and Neary, J. P.(1982). Booming sector and de-industrialisation in a small open economy. The Economic Journal, 92,825-848.

[10] Djankov, S. Montalvo, J. G. and Querol, M. R. (2006). Does foreign aid help? Cato Journal, 26(1), 1- 28.

[11] Hever, S. (2015). How much international aid to Palestinians ends up in the Israeli economy. Aid Watch, $1-15$.

[12] Lucas Jr, R. E. (1988). On the mechanics of economic development. Journal of monetary economics, 22(1), 3-42.

\footnotetext{
12 Agreements to arrange trading system (exporting and importing) using neighboring Arab ports, with a specific pre-determined benefits for these parts, that to avoid the Israeli control of the Palestinian trade system.
} 
[13] McGillivray, M., Feeny, S., Hermes, N. and Lensink, R. (2006). Controversies over the impact of development aid: it works; it doesn't; it can, but that depends. Journal of International Development, 18(7), 1031-1050.

[14] Mishra, S. K., 2008, 'Robust two-stage least squares: some Monte Carlo experiments', Journal of Applied Economic Sciences (JAES), 6, pp. 434-443.

[15] Morrissey, O. (2001). Does aid increase growth? Progress in Development Studies, 1(1), 37-50.

[16] Mosley, P. (1980). Aid, savings and growth revisited. Oxford Bulletin of Economics and Statistics, 42(2), 79-95.

[17] Rajan, R. G. and Subramanian, A. (2011). Aid, Dutch disease, and manufacturing growth. Journal of Development Economics, 94(1), 106-118.

[18] Romer, P. M. (1987). Crazy explanations for the productivity slowdown. NBER macroeconomics annual, 2, 163-202.

[19] Sabra, M. M., \& Sartawi, S. (2015). Development impacts of foreign aid on economic growth, domestic savings and dutch disease presence in Palestine. International Journal of.

[20] Sabra, M. M. (2016). Government size, country size, openness and economic growth in selected MENA countries. International Journal of Business and Economic Sciences Applied Research (IJBESAR), 9(1), 39-45.

[21] Sabra, M. M., \& Eltalla, A. H. (2016). Foreign aid, domestic savings and economic growth in selected MENA countries. Business and Economic Research, 6(1), 352-362.

[22] Sabra, M. M., Eltalla, A. H., \& Alfar, A. R. (2015). The shadow economy in Palestine: Size and causes. International Journal of Economics and Finance, 7(3), 98-108.

[23] Sabra, M. (2021b), FDI and ODA Effects on Recipient Countries Imports Evidence from selected MENA Countries, under publication. The Empirical Economics Letters, 20(8).

[24] Sabra, M (2021a), Does Inward FDI Promote Exports and GDP, Dynamic Panel evidence from Selected MENA Countries. Journal of Applied Economics and Business Research, 11(1).

[25] Stevens, P. (2003). Resource impact - curse or blessing? A literature review. Journal of Energy Literature, 9(1), 1-42.

[26] Tillekens, N. (2010). 71\% of the Aid to the Palestinians Ends Up in the Israeli Economy. Monthly Review Online.

[27] UNCTAD, (1993). Selected Statistical Series on the Balance of Payments, Foreign Trade, Population, Labor Force and Employment (West Bank and Gaza Strip), 1968-1987.

[28] Naqeeb, Fadel, (1997), Palestinian Economy in West Bank and Gaza: Transition Period Problems and Future Policies. Palestinian Studies Institutions. Beirut, Lebanon. (In Arabic). 